\title{
Scale insects (Hemiptera: Coccoidea) infesting apple, apricot, pear trees and their abundant parasitoids in Egypt
}

Shaaban Abd-Rabou, Noha Ahmed and Hoda Badary

Plant Protection Research Institute, Agricultural Research Center, Dokki, Giza

\section{ABSTRACT}

Scale insects are the major pests infesting apple, apricot and pear trees in Egypt. The aim of the present work is to study a survey of scale insects infesting apple, apricot, pear trees and their abundant parasitoids in Egypt. A survey of scale insects infested apple, apricot, pear trees and their abundant parasitoids were carried out all over Egypt during 2009-2011. The results indicated that apple, apricot and pear trees were infested by 19,10 and 10 scale insect species and associated with 12,6 and 8 parasitoid species, respectively.

Key words: Scale insects, apple, apricot, pear trees, Egypt

\section{INTRODUCTION}

Scale insects are the major pests infesting apple, apricot and pear orchards in Egypt. Abd-Rabou (2003) and Bakr et al. (2009) reviewed the scale insects infested different crops in Egypt. Scale insects feed on plant sap. Scale feeding slowly reduces plant vigor, heavily infested plants grow poorly and suffer dieback of twigs and branches. An infested host is occasionally so weakened that it dies. Scales often secrete a sticky honeydew which supports the growth of black sooty molds.

Eleven armored scale insect species attacking 62 host plant species including apple, apricot and pear (Hammad and Moussa, 1973). The host of. Parlatoria oleae (Colvee) (Hemiptera: Diaspididae) was apple (El-Minshawy et al.,1974). Russellaspis pustulans (Cockerell) (Hemiptera: Asterlecaniidae) attacked apple trees in Egypt (Mangoud, 1994). The parasitoids attacking scale insects in Egypt studied by Priesner and Hosny (1940), Hafez (1988), Abd-Rabou (1997, a, b, 1999, 2000, 2001, 2001a), Awadallah et al.(1999) and Evans and Abd-Rabou (2005).

The aim of the present work is to study a survey of scale insects infesting apple, apricot. pear and their abundant parasitoids in Egypt.

\section{MATERIALS AND METHODS}

A survey on scale insects infested apple, apricot, pear trees and their abundant parasitoids were carried out all over Egypt during 2009-2011. Infested plants with scale insects were examined in the field, using a pocket lens. Leaves, stems and twigs were collected and placed separately in paper bags for further examination in the laboratory. Identification of scale insects was made by examining its adult in Canada Balsam, according to Abd-Rabou (2001). Thereafter, the leaves and twigs were kept in a closed paper bags and transferred to the laboratory for further examination and counting. Each leave was stored in a well-ventilated emergence glass tube and monitored daily for parasitoid emergence. 


\section{RESULTS AND DISCUSSION}

As shown in Table (1) the apple trees were infested by 19 scale insect species: 11species belonging to Family Diaspididae, three species belonging to family Pseudococcidae, three species belonging to family Margarodidae and one species of families Asterlecaniidae and Coccidae. During the present work 12 parasitoid species recorded associated with aforementioned scale insects. Table (2) showed that apricot trees infested by 10 scale insect species: 7 species belonging to Family Diaspididae and one species of families Asterlecaniidae, Coccidae and Pseudococcidae. The present work 6 parasitoid species recorded associated with aforementioned scale insects.

Table 1: List of scale insects infesting apple trees and their abundant parasitoids in Egypt

\begin{tabular}{|c|c|c|c|}
\hline Species & Family & Abundant Parasitoids & Date \\
\hline 1. Aspidiotus hederae (Vallot) & Diaspididae & Aphytis chrysomphali (Mercet) & June, 2010 \\
\hline $\begin{array}{l}\text { 2. Dynaspidiotus } \text { britannicus } \\
\text { (Newstead) }\end{array}$ & Diaspididae & Aphytis lingnanensis Comepre & November, 2011 \\
\hline 3.Hemiberlesia rapax (Comstock) & Diaspididae & Encarsia citrina (Craw) & August, 2010 \\
\hline 4. Hemiberlesia latania (Signort) & Diaspididae & Encarsia citrina (Craw) & September, 2010 \\
\hline 5. Icerya aegyptiaca (Douglas) & Margarodidae & Non & October, 2010 \\
\hline 6. Icerya purchasi Maskell & Margarodidae & Non & June, 2010 \\
\hline 7. Icerya seychellarum (Westwood) & Margarodidae & Non & July, 2009 \\
\hline 8. Kilifa acuminata (Signoret) & Coccidae & Coccophagus scutellaris (Dalman) & November, 2010 \\
\hline 9. Lepidosaphes beckii (Newman) & Diaspididae & Aphytis lingnanensis Comepre & July, 2009 \\
\hline 10. Lepidosaphes gloverii (Packard) & Diaspididae & Aphytis mytilaspidis (Le Baron) & October, 2009 \\
\hline 11. Lepidosaphes pallidula (Williams) & Diaspididae & Aphytis chrysomphali (Mercet) & August, 2010 \\
\hline 12. Lepidosaphes ulmi (Linnaeus) & Diaspididae & Encarsia citrina (Craw) & June, 2010 \\
\hline 13. Maconellicoccs hirsutus (Green) & Pseudococcidae & Leptomastix flava Mercet & June, 2010 \\
\hline 14. Melanaspis inopinata (Leonardi) & Diaspididae & $\begin{array}{l}\text { Pteroptrix aegyptica Evans \& Abd- } \\
\text { Rabou }\end{array}$ & October, 2011 \\
\hline 15. Mycetaspis personata (Comstock) & Diaspididae & Encarsia citrina (Craw) & June, 2011 \\
\hline 16. Parlatoria oleae (Colvee) & Diaspididae & Aphytis maculicornis (Mercet) & July, 2009 \\
\hline 17. Planococcus ficus (Signoret) & Pseudococcidae & $\begin{array}{l}\text { Neoplatycerus kemticus Trjapitzin and } \\
\text { Triapitsyn }\end{array}$ & September, 2010 \\
\hline 18. Planococcus citri (Risso) & Pseudococcidae & Leptomastidea abnormis (Girault) & June, 2011 \\
\hline 19. Russellaspis pustulans (Cockerell) & Asterolecaniidae & Metaphycus asterolecanii (Mercet) & August, 2010 \\
\hline
\end{tabular}

Table 2: List of scale insects infesting apricot trees and their abundant parasitoids in Egypt

\begin{tabular}{|c|c|c|c|}
\hline Species & Family & Abundant Parasitoids & Date \\
\hline 1. Aonidiella aurantii (Maskell), & Diaspididae & Encarsia citrine (Craw) & October, 2009 \\
\hline 2. Aonidiella orientalis (Maskell) & Diaspididae & $\begin{array}{l}\text { Pteroptrix aegyptica Evans \& } \\
\text { Abd-Rabou }\end{array}$ & August, 2010 \\
\hline 3. Aulacaspis rosae (Bouche) & Diaspididae & $\begin{array}{l}\text { Habrolepis aspidioti Compere } \\
\& \text { Annecke }\end{array}$ & June, 2010 \\
\hline 4. Aulacaspis tubercularis Newstead & Diaspididae & $\begin{array}{l}\text { Habrolepis aspidioti Compere } \\
\text { \& Annecke }\end{array}$ & September, 2011 \\
\hline 5. Chrysomphalus dictyospermi (Morgan) & Diaspididae & $\begin{array}{l}\text { Pteroptrix aegyptica Evans \& } \\
\text { Abd-Rabou }\end{array}$ & July,2009 \\
\hline 6. Coccus longulus (Douglas) & Coccidae & $\begin{array}{ll}\text { Metaphycus } & \text { lounsburyi } \\
\text { (Howard) }\end{array}$ & October, 2011 \\
\hline 7. Ferrisia virgata (Cockerell) & Pseudococcidae & Blepyrus insularis (Cameron) & July,2010 \\
\hline 8. Hemiberlesia latania (Signort) & Diaspididae & $\begin{array}{l}\text { Habrolepis aspidioti Compere } \\
\text { \& Annecke }\end{array}$ & September, 2009 \\
\hline 9. Melanaspis inopinata (Leonardi) & Diaspididae & Encarsia citrina (Craw) & November, 2011 \\
\hline 10. Russellaspis pustulans (Cockerell) & Asterolecaniidae & $\begin{array}{l}\text { Metaphycus asterolecanii } \\
\text { (Mercet) }\end{array}$ & October, 2011 \\
\hline
\end{tabular}


While Table (3) showed that pear trees infested by 10 scale insect species: 8 species belonging to Family Diaspididae and one species of Families Coccidae and Pseudococcidae. Also during the present work 8 parasitoid species recorded associated with aforementioned scale insects.

Table 3: List of scale insects infesting pear trees and their abundant parasitoids in Egypt

\begin{tabular}{|c|c|c|c|}
\hline Species & Family & Abundant Parasitoids & Date \\
\hline 1. Aonidiella aurantii (Maskell) & Diaspididae & Encarsia citrina (Craw) & July,2009 \\
\hline 2. Hemiberlesia rapax (Comstock) & Diaspididae & $\begin{array}{l}\text { Pteroptrix aegyptica Evans \& } \\
\text { Abd-Rabou }\end{array}$ & June, 2010 \\
\hline 3. Lepidosaphes beckii (Newman) & Diaspididae & Aphytis lingnanensis Comepre & September,2010 \\
\hline 4. Lepidosaphes gloverii (Packard) & Diaspididae & Encarsia citrina (Craw) & June, 2010 \\
\hline 5. Melanaspis inopinata (Leonardi) & Diaspididae & Aphytis chrysomphali (Mercet) & $\begin{array}{l}\text { October, } \\
2011\end{array}$ \\
\hline 6. Mycetaspis personata (Comstock) & Diaspididae & Aphytis sinaii Abd-Rabou & October, 2010 \\
\hline 7. Parasaissetia nigra (Nietner) & Coccidae & Microterys flavus (Howard) & July,2010 \\
\hline $\begin{array}{l}\text { 8. Parlatoreopsis longispina } \\
\text { (Newstead) }\end{array}$ & Diaspididae & Aphytis chrysomphali (Mercet) & September, 2011 \\
\hline 9. Parlatoria oleae (Colvee) & Diaspididae & Aphytis diaspidis (Howard) & November, 2010 \\
\hline 10. Planococcus citri (Risso) & Pseudococcidae & $\begin{array}{l}\text { Leptomastidea } \\
\text { (Girault) }\end{array}$ & September, 2009 \\
\hline
\end{tabular}

Eleven armored scale insect species attacking 62 host plant species including apple, apricot and pear (Hammad and Moussa, 1973). The host of P. oleae was apple (El-Minshawy et al., 1974). R. pustulans attacked apple trees in Egypt (Mangoud, 1994).

Abd-Rabou (1997b) recorded that the parasitoid, Aphytis chrysomphali (Mercet) associated with five armored scale insects in different locations in Egypt. Aphytis diaspidis (Howard) was recorded for the first time in Egypt by Priesner \& Hosny (1940).

Hafez (1988) recorded Aphytis lingnanensis Comepre as the most common species of A. aurantii on Citrus sp. Priesner \& Hosny (1940) recorded Aphytis mytilaspidis (Le Baron) for the first time in Egypt from all over the Nile Delta. Aphytis sinaii Abd-Rabou was collected in a few numbers by Abd-Rabou (2004). Encarsia citrina (Craw) was recorded for the first time in Egypt by Priesner \& Hosny (1940). Abd-Rabou (1997a) mentioned that E. citrina should be considered a promising candidate for utilization in biological control of armored scale insects in Egypt. This species was reared from 8 species of diaspidid scale insects and maximum parasitism rates ranged between 23 and 65\%. Pteroptrix aegyptica (Evans \& Abd-Rabou) was recorded for the first time in Egypt by Evans and Abd-Rabou (2005). Habrolepis aspidioti (Compere \& Annecke) was recorded for the first time in Egypt by Priesner and Hosny (1940). This species reported as an effective parasitoid on different armored scale insects in different locations in Egypt (Abd-Rabou,1997c). Blepyrus insularis (Cameron) was recorded for the first time in Egypt by Awadallah et al.(1999). Leptomastidea abnormis (Girault) was recorded for the first time in Egypt by Abd-Rabou and its reared from $M$. hirsutus with maximum parasitism rate was 21\% (Abd- Rabou, 2000). Leptomastix dactylopii Howard was recorded for the first time in Egypt and its was reared from $M$. hirsutus with maximum parasitism rate was 8\% (Abd- Rabou, 2000). Coccophagus scutellaris (Dalman) collected for the first time in Egypt by Priesner and Hosny (1940). Metaphycus lounsburyi (Howard) was recorded for the first time in Egypt by Abd-Rabou(1998). Microterys flavus (Howard) was recorded for the first time in Egypt and the rate of parasitism of this species on $C$. floridensis, averaged 0.8 and $2.4 \%$ during the two years under considerations, 
respectively. Maximum parasitism rates reached 3.4 and $8.0 \%$ during Mid Nov. and early Nov., respectively (Abd-Rabou, 2001b). M. flavus was mass reared and released at monthly intervals in olive groves infested with S. oleae at three localities in Egypt and percentages of parasitism increased after releasing from 11 to 35\% (Abd-Rabou, 2004).

\section{REFERENCES}

Abd-Rabou, S. (1997): Parasitoids attacking the olive scale insect, Paralatoria oleae (Colvee) (Homoptera : Coccidea : Diaspididae) in Egypt. The first Scientific Conference of Agricultural Sciences, Assuit, Vol., II: 719-726.

Abd-Rabou, S. (1997a): The role of Encarsia citrina (Hymenoptera: Aphelinidae) in the biological control of armored scale insects (Homoptera: Coccoidea: Diaspididae) in Egypt. Proceeding of the First Scientific Conference of Agricultural Sciences, Faculty of Agric. Assiut Univ., Vol. II, 711-717.

Abd-Rabou, S. (1997b): Parasitoids attacking some species of scale insects (Homoptera: Coccoidea: Diaspididae) in Egypt. Proceeding of the First Scientific Conference of Agricultural Sciences, Faculty of Agric. Assiut Univ., Vol. II, 727-736.

Abd-Rabou, S. (1998): The species of genus Metaphycus (Encyritdae : Hymenoptera) from Egypt. Bull. Soc. Ent. Egypt, 76: 67-74.

Abd-Rabou, S. (1999): Parasitoids attacking the Egyptian species of armored scale insects (Homoptera : Diaspipidae). Egypt J. Agric. Res., 77(3): 1113-1129.

Abd-Rabou, S. (2000): Parasitoids attacking the hibiscus mealybug Maconellicoccus hirsutus (Green) (Homoptera : Pseudococcidae) in Egypt. Proceeding of the Scientific Conference of Agricultural Sciences, Faculty of Agric. Assiut Univ. Vol. II: 661-666.

Abd-Rabou, S. (2001): Parasitoids attacking Mealybugs (Homoptera: Coccidea: Pseudococcidae) in Egypt. Egypt. J. Agric. Res. 79 (4): 1355-1377.

Abd-Rabou, S. (2001a): Parasitoids attacking soft scales (Homoptera : Coccidea) in Egypt. Egypt. J. Agric. Res. 79 (3): 859-880.

Abd-Rabou, S. (2003): Scale insects and their management in Egypt. Adv. Agric. Res. In Egypt, Vol. (4) 1: 1-63.

Abd-Rabou, S. (2004): First record of some hymenopterous parasitoids of whiteflies, scale insects and leaf miners in Egypt with description of Aphytis sinaii (n.sp.). Egyptian Journal of Agricultural Research 82(3): 1092.

Awadallah,K.T., Ibrahim,A.M., Atia, A.R. and Nada,S. (1999): Survey of mealybug parasitoids and their associated hyperparasitoids on certain ornamental host plants at Giza region. Bull.Ent. Soc. Egypt. 77:97-101.

Bakr, R. A, Badawy, R. M., Mousa, S. F., Hamooda, L. S. and Sahar A. Atteia(2009) : Ecological and taxonomic studies on the scale insects that infest mango trees at Qaliobiya governorate. Egypt. Acad. J. biolog. Sci., 2 (2): 69- 89.

El-Minshawy, A. M., El-Sawaf, S. K.,Hammad, S. M. and Donia, A. (1974): Survey of the scale inestcs attacking fruit trees in Alexandria district 1 (Fam. Diaspididae; Subfam. Diaspidinae, Trib Aspidiotini. Ale. J. Agric. Res 22 (2): 223-32.

Evans, G. and Abd-Rabou, S. (2005): Two new species and additional records of Egyptian Aphelinidae. Zootaxa, 833: 1-7. 
Hafez, M. (1988): Population fluctuations on parasites of California red scale, Aonidiella aurantii (Mask) (Homoptera : Diaspididae) in Alexandria. J. App. Ent., 106 (2): 183-187.

Hammad, S. M. and Moussa, F. H. (1973): The scale insects attcking ornemntal plants in Alexandria area (Egypt). Alexandria J. of Agric. Res. Vol. 21-August No.2

Mangoud, A. A. H. (1994): Toxicological Studies on some Sucking Insects Infesting Apple Trees. M.Sc. Thesis, Fac. of Agric. Cairo Univ. Cairo, Egypt.

Priesner, A. and Hosny, M. (1940): Notes on parasites and predators of Coccidae and Aleyrodidae in Egypt. Bull. Soc. Ent. Egypte, 24: 58-70.

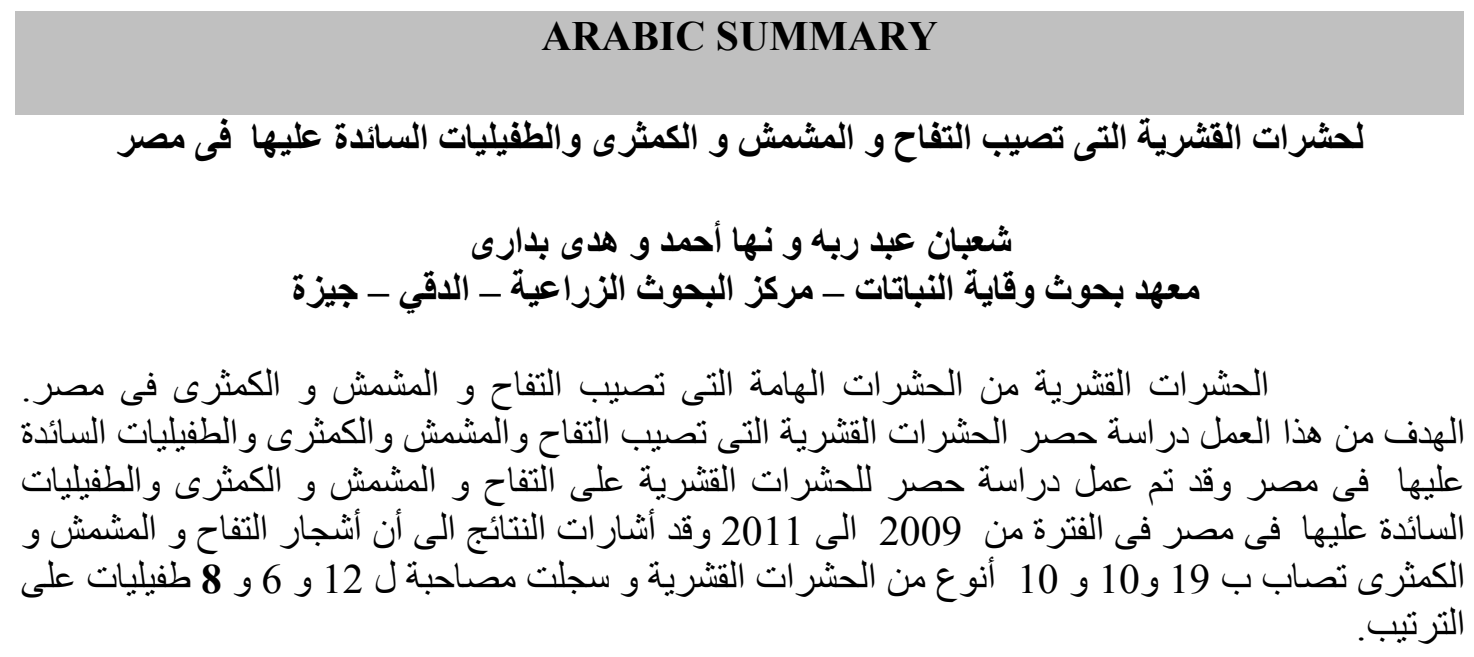

